\title{
SURVEY OF SCREW FEEDERS
}

By

Gordon Sine

February 1983

Work Performed Under Contract No.: DE-AM21-81MC16050

For

U. S. Department of Energy

Office of Fossil Energy

Morgantown Energy Technology Center

Morgantown, West Virginia

By

TRW Energy and Environmental Division

Morgantown, West Virginia 


\section{DISCLAIMER}

This report was prepared as an account of work sponsored by an agency of the United States Government. Neither the United States Government nor any agency Thereof, nor any of their employees, makes any warranty, express or implied, or assumes any legal liability or responsibility for the accuracy, completeness, or usefulness of any information, apparatus, product, or process disclosed, or represents that its use would not infringe privately owned rights. Reference herein to any specific commercial product, process, or service by trade name, trademark, manufacturer, or otherwise does not necessarily constitute or imply its endorsement, recommendation, or favoring by the United States Government or any agency thereof. The views and opinions of authors expressed herein do not necessarily state or reflect those of the United States Government or any agency thereof. 


\section{DISCLAIMER}

Portions of this document may be illegible in electronic image products. Images are produced from the best available original document. 


\title{
DISCLAIMER
}

\begin{abstract}
This report was prepared as an account of work sponsored by an agency of the United States Government. Neither the United States Government nor any agency thereof, nor any of their employees, makes any warranty, express or implied, or assumes any legal liability or responsibility for the accuracy, completeness, or usefulness of any information, apparatus, product, or process disclosed, or represents that its use would not infringe privately owned rights. Reference herein to any specific commercial product, process, or service by trade name, trademark, manufacturer. or otherwise does not necessarily constitute or imply its endorsement, recommendation, or favoring by the United States Government or any agency thereof. The views and opinions of authors expressed herein do not necessarily state or reflect those of the United States Government or any agency thereof.
\end{abstract}

This report has been reproduced directly from the best available copy.

Available from the National Technical Information Service, U. S. Department of Commerce, Springfield, Virginia 22161.

Price: Printed Copy A03

Microfiche A01

Codes are used for pricing all publications. The code is determined by the number of pages in the publication. Information pertaining to the pricing codes can be found in the current issues of the following publications, which are generally available in most libraries: Energy Research Abstracts (ERA); Government Reports Announcements and Index (GRA and I); Scientific and Technical Abstract Reports (STAR); and publication NTIS-PR-360 available from NTIS at the above address. 


\title{
SURVEY OF SCREW FEEDERS
}

\author{
By \\ Gordon Sine
}

February 1983

Work Performed Under Contract No.: DE-AM21-81MC16050

For

U. S. Department of Energy Office of Fossil Energy

Morgantown Energy Technology Center

P. O. Box 880

Morgantown, West Virginia 26505

By

TRW Energy and Environmental Division

Morgantown Office

Chestnut Ridge Professional Building

Morgantown, West Virginia 26505 


\section{THIS PAGE \\ WAS INTENTIONALLY \\ LEFT BLANK}




\section{ABSTRACT}

This report presents the results of a survey to determine the availability of screw feeders for use in areas related to coal feeding in the field of coal conversion. 
1.0 EXECUTIVE SUMMARY . . . . . . . . . . . . . . . . . . . . . . 1

2.0 INTRODUCTION . . . . . . . . . . . . . . . . . . . . . . . . 9

3.0 SURVEY METHOD . . . . . . . . . . . . . . . . . . . . . . . . . . 11

4.0 SURVEY RESULTS . . . . . . . . . . . . . . . . . . . . . . 12

5.0 CONCLUSIONS . . . . . . . . . . . . . . . . . . . . . . . . . . . 23

6.0 RECOMMENDATIONS . . . . . . . . . . . . . . . . . . . . . 25

7.0 DIDLIOGRAPHY . . . . . . . . . . . . . . . . . . . . . 26

8.0 APPENDIX . . . . . . . . . . . . . . . . . . . . . . . . . . 28

Table I Summary of Responses to Screw Feeder Survey Letter . . . . . . . . . . . . . . . . . . . . 


\subsection{EXECUTIVE SUMMARY}

Advanced processes for coal conversion tend toward higher temperatures and pressures. This results in a pressure boundary between the pressurized reactor and the unpressurized feedstock. Present methods of transporting the atmospheric coal feed to the pressurized reactor include lockhopper systems for dry feed and pumping systems for wet (slurry) feed. Both systems are energy consumers in that lockhoppers require pressurization media, often an inert gas mixture that can also affect product gas composition, and slurries introduce excessive moisture that must be treated. An alternate method to cross the pressure boundary directly would be to use a dry pumping technique that would inject the feed and act as a seal at the same time. Some success has been demonstrated with screw extruders during a project to develop new concepts of coal feeding. This survey was undertaken to determine the availability of screw feeding equipment that could accomplish this function, viz., the replacement of lockhopper feed systems for pressurized reactors.

A direct mail approach was selected for the survey. A letter requesting specific information relative to feeder capability in the areas of differential pressure, feed rates, feed coal size range, feeder size, temperature limitations, specific power consumption, and design details was drafted. A list of knowledgeable sources was prepared; this included manufacturers, organizations/trade associations, and individuals. The list was derived from various references including:

a) Keystone Coal Industry Manual

b) Thomas Register

c) Encylopaedia of Associations

d) Proceedings of the Workshop on Critical Coal Conversion Equipment, October 1-3, 1980; the AIChE Annual Meeting (Coal Feed Systems Portion) June 7-10, 1982; and the Coal Feeder Development Workshop, Octoner 13-14, 1982

e) Buyers Guides of Technical Journals such as Chemical Engineering and Coal Age

f) input from various individuals involved in coal projects. The letters drafted and the compiled miling list are included in the Appendix.

The letter was sent to fifty-five manufacturers, organizations, and individuals associated with screw feeders. Twenty-five responses were 
obtained and reviewed. In addition, six individuals in various capacities in the major trade organizations were identified. Six of the more promising manufacturers were selected for follow-up contact. This information is summarized in Table I. Phone calls were made and resulted in several additional references who were also contacted by phone. One of these additional references had recently performed a study to determine the status of biomass feeders for the Canadian Forestry Service and a copy of his report "Status of Bio-Mass Feeder Technology" was obtained and reviewed.

Over seventy contacts were made and only two responses reflected off the-shelf screw lype coal feeder availability. Another responder Indicated that he thought he had equipment to do the job, but had no published data on it (it was used for wood chip feeding but the conversion to coal was felt feasible). And one more was going to assemble some standard components and perform feasibility tests at atmospheric pressure because so many inquiries had recently been received. However, most of those contacted were unaware of any activity in the field. The remainder were somewhat familiar with the DOE sponsored coal feeding devices but knew of no industry sponsored efforts.

One of the commercially available items, the Type M Fuller-Kinyon pump from the Fuller Company, basically feeds a pneumatic transport system and is limited to the 50 to 100 psid (psi differential pressure) range and reedstock in the $-\frac{1}{4}$ nominal range. Their main area of activity is in feeding atmospheric fluidized bed boilers.

The oiher unit, a co-rotating twin screw extruder of the ZSK type, from Werner \& Pfleiderer of Stuttgart, Federal Republic of Gerimany, requires approximately $20 \%$ molsture to be added and is also 1 imlted in teedstock size to the $-1 / 4$ inch range. It does feed into high pressurcs having delluristrated 1500 psid operation at $860 \# / h r$ throughputs. A unit was also supplied to VFRA Del $\mathrm{Mg}$ in the Federal Kepublic of Germany to feed a gasifier nperating near 850 psig. A copy of the report describing the results of this use was requested from $V E B A$.

The survey is complete. Two screw type machines were found that are used to feed coal against a differential pressure. Both are limited to the size of feed they will accept, $-1 / 4$ inch. One is a dry feeder that operates in the 50 to 100 psid range. The other develops high pressure (1500 psid) but requires the addition of about $20 \%$ moisture. 
The Bio-Mass Feeder Technology report was reviewed and lists several additional commercial feeders that have been used to feed wood material to pressurized (approximately 150 psig) reactors: the Koppers Company, Inc. Plug Screw Feeder, the Stake Technology "Co-Axial Feeder", (mentioned earlier as having no published data available), and the C.E. Bauer Pressafiner. Sunds Defibrator Ltd. and Rise Louise Corp. are listed for lower pressure ( 40 psig) applications.

It is concluded that commercial screw feeders do exist that may replace lockhopper feed systems for feeding coal to pressurized reactors. However, there is little evidence (with the exception of the Type M Fuller-Kinyon pump) to support the contention that the feeders are commercially proven in the area of pressurized coal combustion or gasification and there is less evidence that they are regarded as. "standard" in the industry. 
Table I

Summary of Responses to Screw Feeder Survey Letter

1. Manufacturers Acrison Inc. Bechtel National Bloom Inc.

A.E. Bogott \& Sons, Inc. Buck-El Inc.

Conspray Construction Sys tems, Inc.

\begin{tabular}{|l|l|l|l|} 
Brochure & $\begin{array}{l}\text { Tecinical } \\
\text { Datz }\end{array}$ & Experience & $\begin{array}{l}\text { Do not } \\
\text { make feeder } \\
\text { for this } \\
\text { applicaticn }\end{array}$ \\
\hline
\end{tabular}

[ivine Engineering, Inc. Ducon Company, Inc.

Duplex Mill \& Manufacturing Co.

James Eagen \& Sons Co.

Eriez Magnetics

Feedmatic-Detroit, Inc. ${ }^{2}$ Ferro-Tech, Inc.

Flex-Kleen Corp.

FMB Systems, Inc.

${ }^{2}$ FMC Corp.
NO RESPONSE

Not a screw feeder Positive displacement piston.

Rotary feeder, limited differential pressure. Supplied information on Thomas \& Muller.

Make flights \& feedscrews only, not complete feeders.

Magnetic equipment \& conveyors; vibratory feeders.

Al1 types of agglomeration process equipment. 
Table I (Cont.)

Foster-Miller Associates, Inc.

${ }^{2}$ Fuller Company

General Electric Co. Henderson Industries Horst Dynamics, Inc. IFE Systems, Inc.

Ingersol ]-Rand

Jeffrey Manufacturing Kinergy Corporation

K-Tror Corporation Lively Manufacturing and Equipment 50 .

Lockheed

M.MM Mars Mineral

Metalfab, Inc.

Mikropul Corporation

Moksnes $\mathrm{Mfg}$., Inc.

Nash International Inc.

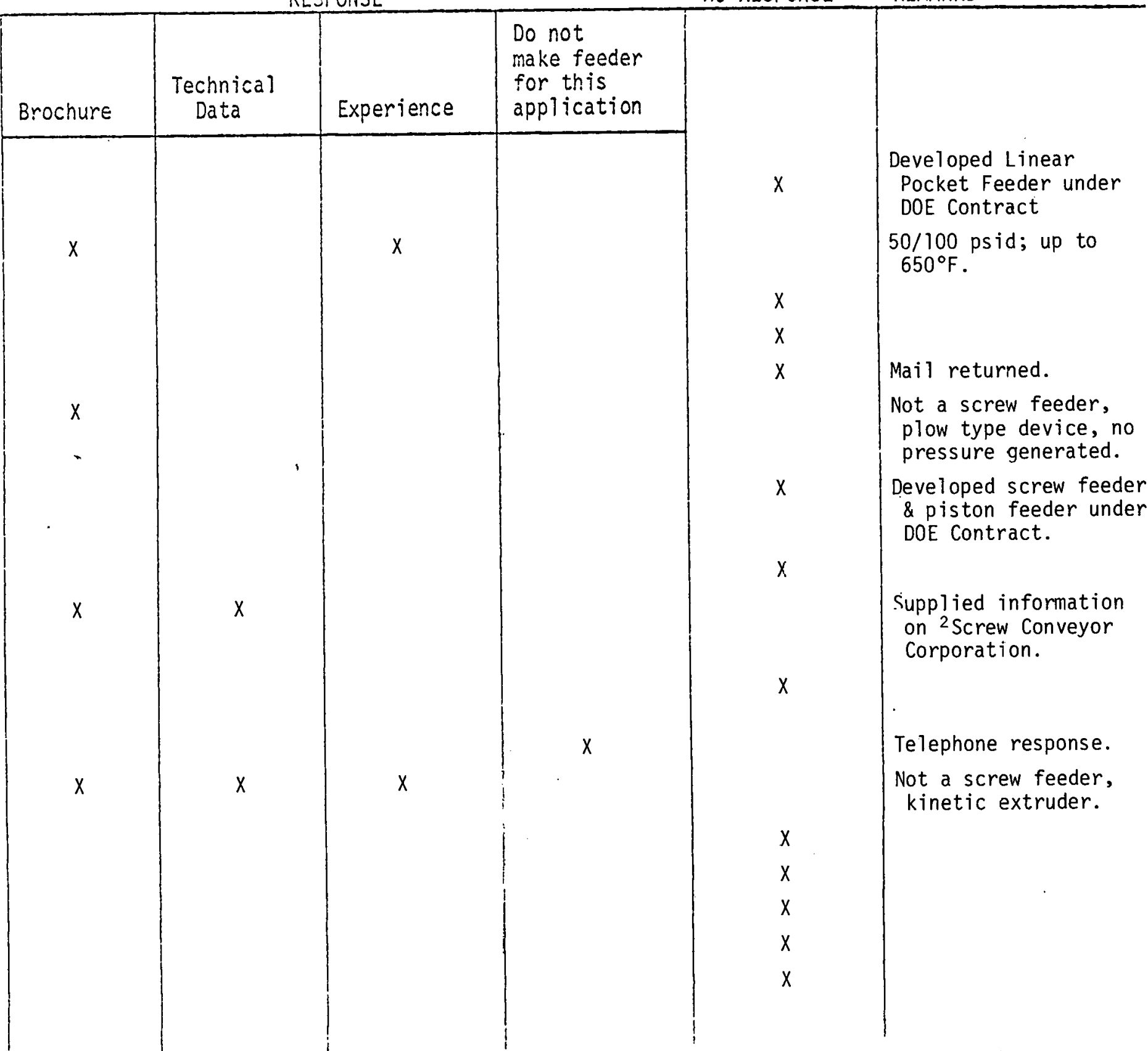


Table I (Cont.)

New Castle Industries, Inc.

Nott Company

Penn Bangor, Inc.

Petrocarb, Inc.

Sprout-Waldiron

${ }^{2}$ Thomas \& Muller Co., Inc

Union Carbije

Vibranetics, Inc.

Vibra Screw, Inc.

2Werner \& Pfleiderer Corp

Willis \& Paul Engineer Inc.

Wyssmont, Inc.

\section{Organizations}

Association of Professional Material Handling Consultants (APMHC)

Conveyor Equipment Manufacturers Association (CEMA)

Broch

\section{Do not}

make feeder

for this application

$x$
$x$

$x$
$x$
$x$
$x$

No coal experience.

Not a screw feeder.

Pneumatic system,

600 psic, lock-

hopper type.

Some experience at

low pressure dif-

ferential (2-5 psi).

Mail retuaned.

Co-rotating twinscrew extrustion.

Not a screw feed, rotary type, low differential (airlock).

Provided roster.

Purchased technical specifications ANSI/ CEMA $550-1980,300-$ $1981,350-1981,102-$ 1982; 1982-1983 Roster. 
Tabie I (Cont.)

RESPONSE

\begin{tabular}{|l|l|l|l|}
\hline Brochure & $\begin{array}{c}\text { Technica? } \\
\text { Data }\end{array}$ & Experience & $\begin{array}{l}\text { not } \\
\text { make feeder } \\
\text { for this } \\
\text { application }\end{array}$ \\
\hline & & & \\
\hline
\end{tabular}

Deep Foundations Institute

International Material

Management Society

Material Handling Equipment Distributors

Association

Material Handling

Institute

$\checkmark$

Petroleum Equipment Suppliers Association

3 Individuals

Bill Borsch3

Eric Carlson ${ }^{3}$

Bob Footlik ${ }^{3}$

George Gross ${ }^{3}$

Don W. Lewis
NO RESPONSE REMARKS

Management education programs for distributors.

Industrial coal conversion processes screw feeders out of scope.

CEMA Representative no direct experience. I:EMA Representative no direct experience. APMHC Representative no direct experience.

APMHC Representative no direct experience. Jet Propulsion Laboratory researcher. Recommended additional sources. 
Tatle I (Cont.)

\section{James L. Powel1}

David Schaefer ${ }^{3}$

George Schultz ${ }^{3}$

Donald H. Wilson ${ }^{3}$

Subtotals

MFG ORG IND

$\begin{array}{lll}45 & 7 & 9\end{array}$

TOTALS

b]

Brochure indicates a bulletin Jescribirg the feeder was subritted.

Technical Data irdicates dimehsionel a.id/or performance data were submitted.

Experience indicates that tie feeder has been ised to feed cr transport coal.

2Manufacturers selected for =of ow-l.p phone calls.

${ }^{3}$ Telephone contact only.

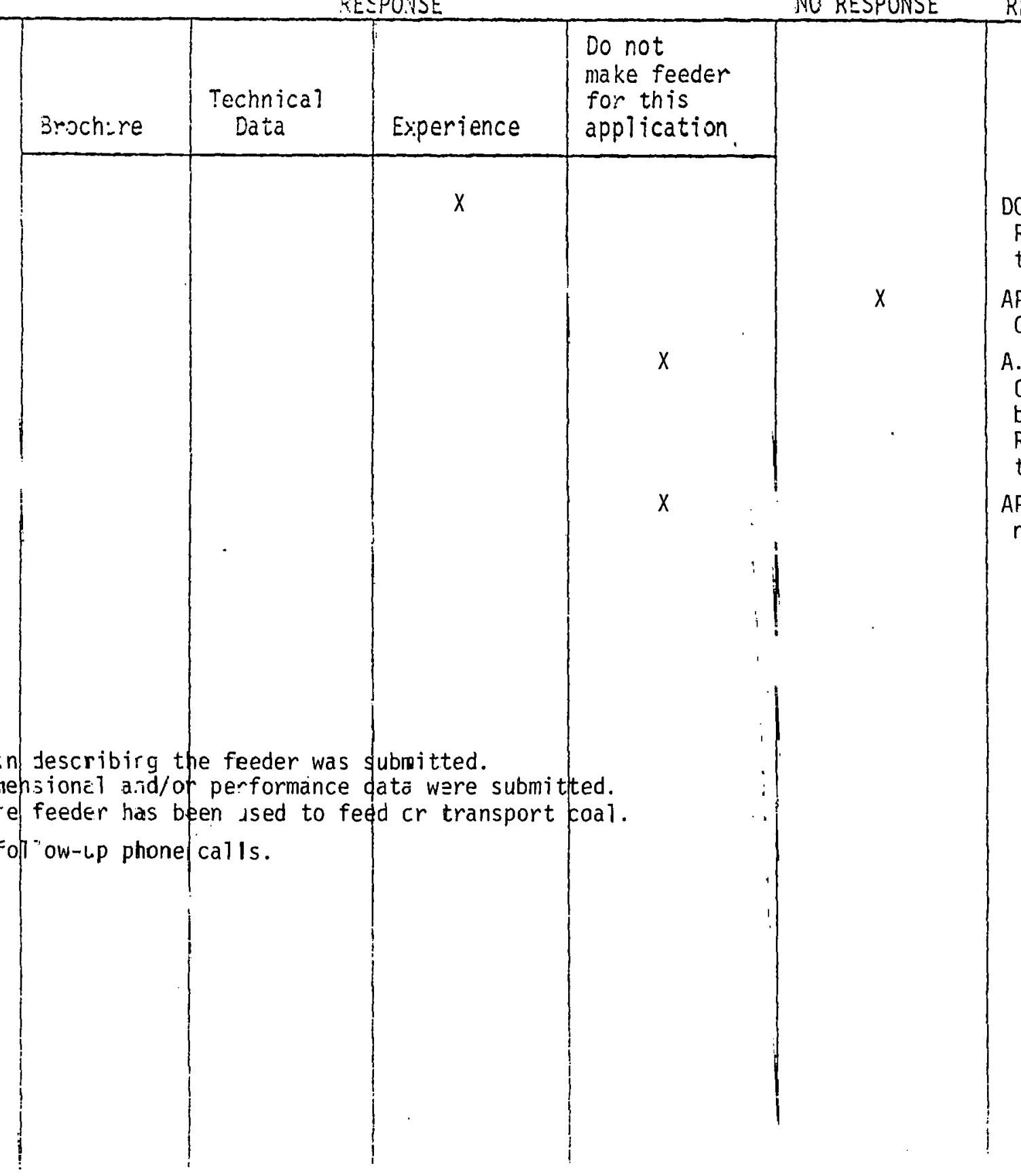

DOE Headcuarters. Recommerided add $i$ -

tional sources.

APMHC Representative.

Could not contact.

A. Epstein \& Sons, Chicago. Referred by R. Footl ik, APMHC. Recommended additional scurces.

APMHC Representative no direct experience. 


\subsection{INTRODUCTION}

Means to alleviate the dependency of the United States on foreign $0 i 1$ include the efficient and environmentally sound use of coal. Pressurized coal gasification and combustion processes promote this objective. A method of feeding coal from atmospheric pressure to the pressurized reactors is required. Present techniques include lockhopper systems for dry feed and slurry pumping systems for wet feed. Both, while successful, result in wasted energy.

Lockhopper systems require a pressurizing medium and a method for venting. If external medium, e.g., an inert gas, is used, it must be compressed to at least system pressure. Further, depending on the volumes invoived, it could affect product gas quality and/or combustion efficiency. If process gas is used, it must be vented resulting in lost product and perhaps environmental problems. Germany and England are attempting to improve Tockhopper operation by using a device with a piston to sweep the process gas (pressurizing medium) from the hopper back to the process prior to depressurizing the hopper for the next batch load from atmospherel. One such device is the Lurgi-Schlepper Feeder where a sealing piston replaces the top or atmospheric valve ${ }^{2}$.

Slurry systems require considerable amounts of liquid, nominally water and typically over $50 \%$ by weight. While some of this water may be used in process reactions, the remainder tends to lower process temperatures and subsequently results in some sort of wastewater treatment, both of which are energy consuming.

What is really desired for coal feeder applications is a metering pump thal handles a solid feedstock. of various consistencies and requires little power while developing substantial equivalent head.

Some confusion exists relative to terms used in coal feeding. However, this confusion does not exist in the materials handling industry as represented by the Conveyor Equipment Manufacturers Association (CEMA). Their terms are well defined. A conveyor is a device that basically transports material from one place to another. The material can be heated, cooled, dewatered, etc.

${ }^{1}$ Coal R\&D, Vol. 6 No. 2, Casey Publishing Company, February 2, 1983.

2 "Status of Biomass Feeder Technology" by B.H. Levelton \& Associates Ltd. Contractor's Final Reporl, DSS Contract 43SS. KN107-1-4420, ENFOR Project C-259, December 1982. 
en route but this is incidental to the basic function of transport. A feeder is a device that meters or controls the flow rate of a material. It is often used in conjunction with a conveyor. Extruders are not addressed by CEMA but are customarily thought of as processing equipment as opposed to transporting equipment. The function of an extruder is to change the state of the feedstock, e.g., plasticize pellets to some formed shape. That is, a solid material is plasticized or melted and then forced through a die and solidified. Normally high internal pressures are associated with extruders while conveyors operate at one atmosphere.

The United States DOE has and is sponsoring the development of coal feeders, particularly to supply coal to pressurized reactors. This development has been proceeding since 1975. An ideal feeder would take run-of-mine coal as delivered and without beneficiation or additives deposit it at a prescribed rate in a pressurized reactor for processing. This entails three steps: (1) transporting, (2) metering, and (3) sealing.

Several techniques to accomplish this were/are being pursued in the DOE program. Primary among them are: a I inear-Pocket Fceder by Foster-Miller Associates, Inc.; a Coal Screw Feeder by Ingersoll-Rand Research, Inc.; a Kinetic-Extruder Feeder by Lockheed Missiles and Space Company; a Cól Piston Feeder by Ingerso11-Rand Research, Inc.; and a Dynamic Sleeve Piston Feeder by Conspray Construction Systems, Inc. A11 of these devices have demonstrated proof of concept and are now ready for qualification or long term testing to determine reliability and performance under commercial environments. This will entail considerable expense since installation on a pilot scale gasifier or combustur is required. Seven years have past since the inception of the DOE sponsored coal feeder development program. In this time frame considerable activity has occurred in the energy arena. Screw feeders and conveyors are one of the most popular materials handling system and the one most likely to be adaptable to differential pressure application (without the use of isolation or lockhopper type devices). It was therefore deemed appropriale to ascertain if commercial screw feeder equipment had been independently developed over this time frame. If there was commercial equipment available with some operation history it would lessen or negate the need for government (DOE) to perform long term reliability testing. 


\subsection{SUIRVEY METHOD}

A direct mail approach was selected for the survey. A letter requesting specific information relative to feeder capability in the areas of differential pressure, feed rates, feed coal size range, feeder size, temperature limitations, specific power consumption, and design details was drafted.

Contacts for the screw feeder survey were obtained from various sources within the coal and synfuels industry. Trade journals, material buyers guides, newsletters, and individuals were gleaned to obtain a list of initial contacts for off-the-shelf equipment and state-of-the-art or developed technology. These contacts included manufacturers, organizations/trade associations, and individuals. The list was derived from various items including:
a) Keystone Coal Industry Manual
b) Thomas Register
c) Encylopaedia of Associations
d) Proceedings of the Workshop on Critical Coal Conversion Equipment, October 1-3, 1980; the AIChE Annual Meeting (Coal Feed Systems Portion) June 7-10, 1982; and the Coal Feeder Development Workshop, October 13-14, 1982
e) Buyers Guides of Technical Journals such as Chemical Engineering and, Coal Age
f) input from various individuals involved in coal projects.

Each source was reviewed with special emphasis on coal and screw feeders. The names appearing most often throughout the entire range of documentation were selected for the survey. The letters drafted and the compiled mailing list are included as Appendix A.

A direct mail canvass was made and the responses were screened for follow-up telephone contact. The criterion for follow-up was basically that the responder made a screw feeder/conveyor that had been used in a coal application. These follow-up contacts in turn led to additional leads who were also contacted by phone. Requests for documentation relative to performance and screw feeder design were made of each contact. 


\subsection{SURVEY RESULTS}

The letters requesting information were sent to 45 manufacturers, 7 organizations, and 2 individuals. No response was received from 27 manufacturers and 3 organizations. Five manufacturers indicated they did not make a feeder for this application, i.e., to feed across a pressure boundary and provide a seal. Six made feeders that were other than screw feeders, e.g., rotary feeders. One had no experience with coal and one had experience but used components made by a separate manufacturer. Five indicated screw feeders with coal experience. Four organizations indicated they were not aware of feeders for this application; one supplied a roster of members, onc provided exlensive technical standards, and two were generally not involved with feeders per se. The two individuals contacted provided information from their experience and supplied additional contacts. However, the experience was primarily with the DOE sponsored feeder work. Four individuals were selected from the roster supplied by the Association of Professional Material Handling Consultants (APMHC) and were contacted by phone. None were able to supply any direct information but one did supply an additional contact. Two individuals were selected from the Standards supplied by the Conveyor Equipment Manufact.urers Assuclation (CEMA). They were contacted by phone but were unable to provide information relative to this application, Results of the initial contacts are summarized in Table I.

Based on the above, six manufacturers were selected for follow-up. They were:

Ferro-Tech

FMC Corporation

Fuller Company

Screw Conveyor Corporation

Ihomas \& Muller Co., Inc.

Werner \& Pfleiderer Corporation 
Telephone conversations were held with these six manufacturers selected from screening the initial responses to the survey questions. The results of these conversations follow.

\section{Ferro-Tech ${ }^{3}$}

Ferro-Tech is located at 467 Eureka Road, Wyandotte, Michigan 48192, . telephone (313) 282-7300. Discussions were held with Carl A. Holley, President, on several occasions during January and February 1983. Ferro-Tech is primarily involved in agglomeration process development and equipment manufacture. Feeders are incidental to their primary function of agglomerating materials. Ferro-Tech is presently involved in bio-mass activities but they have extensive experience with numerous materials including coal and have used screw type extrusion machines to produce coal logs. They have also used pelletizers and briquetters to agglomerate coal dust, filter cake, and fines. However, Ferro-Tech indicated they did not feel their equipment would be appropriate for differential pressure applications at this time. They knew of no off-theshelf equipment on the market that would perform the function desired. The name of a consultant, Tom Miles, who was knowledgeable in the feeding of bio-mass, particularly wood products was supplied. Ferro-Tech also suggested talking to J.C. Steele \& Sons, Inc. relative to extruders.

Thomas R. Miles, Consulting Design Engineer, 5475 S.W. Arrow Wood Lane, Portland, Oregon 97225, telephone (503) 292-0107 was contacted. He has had 35 years' experience as a materials handling consultant primarily in the wood products industry and is presently involved with biomass (woodchip) feeders for gasifiers. Tom says he knows of no device that will do what we want. He has been working on several projects involving feeding biomass to pressurized reactors (1000 \#/hr o $300 \mathrm{psig;} 600 \mathrm{\# /hr}$ ( $150 \mathrm{psig).} \mathrm{However,} \mathrm{no} \mathrm{differential}$ pressures are involved. The feeders are downstream of a lockhopper type system that isolates the reactors from the atmosphere. He hypothesized that the feeders

\footnotetext{
See Bibliography for references.
} 
he was using could possibly seal up to 50 psid (psi differential pressure) but that the plug integrity was absolutely unreliable, at least with woodchips. He suggested talking to Wayne Edwards who had just completed a survey similar lu ours relative to biomass feeders.

Jim Pickett was contacted by phone at J.C. Steele \& Sons, Inc., 710 South Mulberry St., Statesville, NC 28677, telephone (704) 872-3681. Jim indicated that they made extruders to reclaim coal fines by forming them into coal logs. This was not done at a differential pressure but he felt that it was feasible. However, some development work would be required to determine feedstock limitations, sealing capabilities, atc. So while he envisions hts equipment being able to do the function we want. it. would require a duvclopment effort to verify it.

Wayne Edwards, B.H. Levelton and Associates Ltd., 8805 0sler Street, Vancouver, British Columbia, Canada V6P 4G1, telephone (604) 266-1411, was telephoned. He indicated that he had recently completed a study for the Canadian Forestry Service on the Status of Biomass Feeder Technnlogy and suggestcd obtaining a copy of the report. This was done. He also suggested calling Stake Technology Corp. in 0akville, Ontario as they might have a feeder that would work in the 250 poid range.

The Canadian report, "ENFOR Project C-259, Status of Biomass Feeder Technology" is comprehensive and is recommended to all who desire an overview of foeder technology. It points out that feeders available for use on pressurized systems include: lockhopper, linear pocket, piston, rotary, and screw types. Many of the designs for higher differential pressures have not been used for wood residues but originated from a development. program funded by the U.S. Department of Energy for feeding pressurized coal gasifiers. The findings of the report state that, at differential pressures up to 145 psid, several well-proven feeders are available for feeding wood chips and sawdust. These include lockhopper, rotary, and screw feeders. Some examples of Tockhopper systems are Lurg1 Coal Luck, Petrocarb Pneumatic, and Miles Biomass; rotary feeders are Bauer, Kamyr, and Beaumont; screw feeders include Sunds Defibrator Ltd. (40 psid), Rise Louise Corp. (7 psid), Fuller-Kinyon, Type M (50 psid), and Koppers Company, Inc., Sprout Waldron Div. (150 psid). The screw feeders listed as potential high-pressure feeders for wood residues are: C. E. Bauer Pressafiner, General Electric Screw Feeder, Ingersoll-Rand Screw Feeder, Koppers Screw Feeder, Stake Technology Screw Feeder and the Werner \& Pfleiderer Screw Feeder. Of these, the Bauer, Koppers, and Stake units have proven operation with wood residues. The Werner \& Pfleiderer 
unit has demonstrated it can operate with wood residues.

The Koppers Plug Screw Feeder is commercially available. Wood chips form a plug in a tapered spool prior to injection into a pressurized steaming vessel. Typical differential pressure is 150 psid. Calls were made to several areas within the Sprout-Waldron Division. They do make plug screw feeders for various applications. One is used to feed pet food to steam cookers and operates at 15 to 20 psid with no blowback problems (Glenn Falk). Another is used in the pulp and paper area at about 150 psid and seals against steam. It has only been used on wood products to date. There has been no experience using coal. Design and test effort would be required before a coal application could be considered because of the considerable difference in the materials (coal vs. wood chips) properties. In short, to use the biomass plug screw feeder for coal applications would take some development work; it could probably not be used "off-the-shelf" (Jim Foresman).

The Stake Technology unit is a "Co-Axial Feeder" in which a feed material is metered to a single compression screw and the precompacted "plug" is moved forward against a choke by a reciprocating piston. Most service has been at a differential pressure of 350 psid. A call was made to Igor Fridrich at Stake Technology Limited, 220 Wyecroft Road, Oakville, Ontario, Canada, L6K 3V1, telephone (416) 842-4560. Igor stated they have built ten machines to custom requirements for biomass feeding; one unit fed 18,000 $\mathrm{ft}^{3} / \mathrm{hr}$ (approximately 180 tons $/ \mathrm{hr}$ ) at $500 \mathrm{psid}$. They have no experience with coal but feel very confident their machine would work and are very interested in working on development in this area.

The Bauer Pressafiner was designed for high pressure (1000 psid) de-watering of pulps but may be considered a feeder. A truncated conical feed screw provides initial compression and eliminates voids. The material is compressed about 4 to 1 as it moves along lhe screw. Liquid is "squeezed" nut through a unique screen device. The long feed screw forms a plug to seal against back pressure from the pressurized reactor. Telephone conversation with Larry Tantello at C. E. Bauer, P.0. Box 968, Springfield, Oh io 45501, telephone (513) 390-3400, 
indicated that Bauer deals in wood products and has little or no experience with coal. He felt the abrasiveness of coal would be a problem. The Pressafiner is in fact a screw press and the item more appropriate for our use would be a plug screw feeder. They do make one but it is 1 imited to about 100 psid and has not been used for coal.

This concludes the results obtained from the Ferro-Tech contact, FMC Corporation ${ }^{4}$

FMC Curporatyon, Material Handling Equipment Division is Tocated in Tupelo, Mississippi 38801 (Box 1370), telephone (601) 869-5711. FMC manufactures Link-Belt Screw Conveyors and Screw Feeders and their equipment is backed by extensive field experience. They have pioneered in the development of screw conveyor components and accessories and their production facilities have kept pace with advancements in design. They have handled a variety of materials including coal in sizes ranging from fines to a combination of fines and lumps. Their cataloq provided information to enablc selection uf uff-the-sheitt equipment and provided dimensional data also. In addition they suggested contacting the Conveyor Equipment Manufacturers Association (CEMA) at 1000 Vermont Ave. N.W., Washington, D. C. 20005, telephone (202) 628-1634 to obtain - design specifications and standards for off-the-shelf equipment. This was done.

Subsequent phone calls to FMC indicated that FMC is not involved with feeders that produce any sort of plugging action. They have not done work of this sort in the past and it is not their product line at this time. Such an item would certainly not he nff-the-shelf and would have lu be an "engineered order". It (the sealing requirement) is considered to be out. nf the field of expertise for materials handling people. They would he willing to fabricute equipment to order (i.e., to customer supplied drawings) but doubted they would be able to warrant performance.

\footnotetext{
${ }^{4}$ See Bibliography for references.
} 
CEMA was contacted and the following items were purchased:

$\begin{array}{ll}\frac{\text { Standard No. }}{\text { CEMA No. 102-1982 }} & \begin{array}{l}\text { Title } \\ \text { Conveyor Terms and } \\ \text { Definitions }\end{array} \\ \text { ANSI/CEMA 300-1981 } & \begin{array}{l}\text { Screw Conveyor } \\ \text { Dimensional Standards }\end{array} \\ \text { ANSI/CEMA 350-1981 } & \text { Screw Conveyors }\end{array}$

ANSI/CEMA 550-1980 Classification and Definition of Bulk Materials

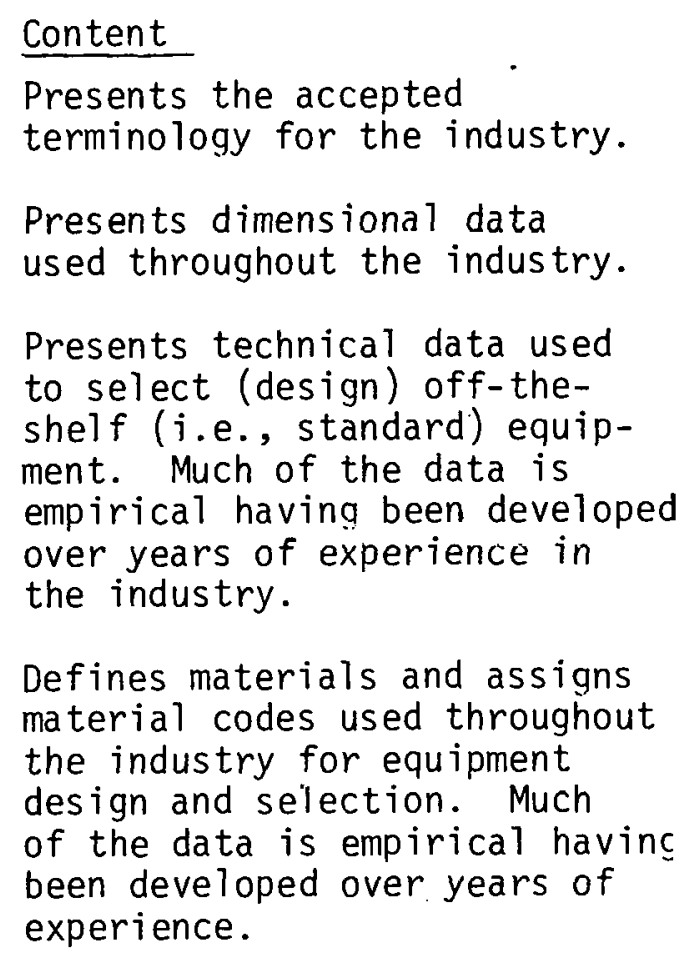
ment. Much of the data is empirical having been developed over years of experience in the industry.

Defines materials and assigns material codes used throughout the industry for equipment design and selection. Much of the data is empirical having been developed over years of experience.

These publications are standards for the industry and several have been adopted by the American National Standards Institute. Therefore, when talking about off-the-shelf "commercial" equipment, these standards apply "since most a)1 reputable major manufacturers subscribe to their standards" (FMC). Fuller Company ${ }^{5}$

Fuller Company is located at 2040 Avenue C, P.0. Box 2040, Bethlehem, PA 18001 , telephone (215) 264-6011. Fuller has over 50 years' experience in coal handling systems. Initial activities with the Fuller-Kinyon pump were related to el iminating

${ }^{5}$ See Bibliography for references. 
the explosion hazard involved in conveying pulverized coal. They have seen extensive use on atmospheric fluidized bed combustion facilities including the demonstration unit (30 megawatt) at Rivesville, WV. The Type M FullerKinyon pump has successfully fed solids at a differential pressure of 50 psi and development of 100 psid capability is progressing. Coal size of $1 / 2^{\prime \prime} \times 1 / 4^{\prime \prime}$ has been conveyed; $650^{\circ} \mathrm{F}$ is the upper temperature 1 imit for the pump. A telephone conversation with Fuller revealed the basic usc of the Type M Fuller-Kinyon pump is to introduce atmospheric coal into a 50 to $10 n$ nsing pneumatic conveying system while maintaining a continuous material (coal) seal. A flapper type check valve provides a safety feature. A plug is not formed, however, and this more or less limits the basic Type M pump to the 50 to $100 \mathrm{psid}$ range. The largest pump made to date has a capacity of 150 tons/hour; most of the pumps in use are in the 10 to 20 tons/hour range and are used on atmospheric fluid bed boiler applications. The Biomass Feeder Technology report stated a $100 \mathrm{~mm}$ (approximately 4 inches) Fuller-Kinyon pump had been modified to a plug screw feeder to feed a pressurized vessel. No blowback was observed when feeding minus $6 \mathrm{~mm}$ (about 1/4 inch) coal at 8 tonnes/hour (ahnut 17,650 \#/hr) against a differential of $620 \mathrm{kPa}$ (about $90 \mathrm{psi}$ ). $25 \mathrm{~kW}$ power was required resulting in a specitic power consumption of $3.8 \frac{\mathrm{h} p}{\text { ton/hour }}$. Kinergy Corporation/Screw Conveyor Corporation 6

Kinergy Corporation is located at 4821 Jennings Lane, Louisville, Kentucky 40218, telephone (502) 964-5901 and are designers and manufacturers of hilk materialc handling equipment. Sorew Conveyor Corporation is localed dt 700 Hoffman Street, Hammond, Indiana 46327. telephone (219) 931-1450 and are manufacturers of a full line of screw conveyors and other bulk handling equipment.

Kinergy Corporation responded to the survey and presented information relative to their knowledge of screw feeder designs. They indicated that most screw feeders (commercial, off-the-shelf) are manufactured to a "standard" format and enclosed a Screw Conveyor corporation catalog as an example. (These follow closely the CEMA documents.) They were not aware of any user

${ }^{6}$ See Bibliography for references. 
where a screw feeder or conveyor could develop and seal a differential pressure. The suggestion was made that an airlock type device be used to maintain the entire feeder at pressure or be on the downstream side of the feeder. A subsequent call to Kinergy revealed that screw feeders were treated as an accessory at Kinergy and that our application would require a very special design. Kinergy had no experience in this area and, to their knowledge, there was no off-the-shelf equipment that would do the job. Screw Conveyor Corporation makes standard screw feeders and components for all types of applications and Kinergy suggested calling them as they would likely know if a "commercial" feeder for our application was available. Screw Conveyor Corporation was contacted by phone. They know of no application where screw conveyors/feeders are used to generate a differential pressure. They have made a lot of screw feeders but none to do this sort of application. They have done a lot of work with coal but none at differential pressure. They have made feeders for pressurized service but have had "locks" on one or both ends. From their experience, the design would take a lot of engineering. They doubt if coal above 1/8" maximum could be made to seal without a binder, paste, or something to fill in the voids. The forces required would probably stall the screw, bend the flights, strip the flights, or result in some other damage. They would be glad to fabricate to customer supplied prints but could not be responsible for the design. They know of no standard "off-the-shelf" hardware that could perform this function.

Ducon Company, Inc./Dravo Duyle/Thomas \& Muller Co., Inc. ${ }^{7}$

Dravo Doyle, 995 Manor Oak Two, 1910 Cochran Road, Pittsburgh, PA 15220, telephone (412) 343-9850 responded to the survey as representatives of Ducon Fluid Transport Division, Ducon Company, Inc. They pointed out that Ducon does not make screw feeders. However, they also represent Thomas \& Muller who do and they enclosed a bulletin from them. Thomas \& Muller is located at Box 1930, Camden, New Jersey 08101, telephone (609) 963-3500. They make custom designed, custom built, feeders as well as standard feeders. Folger Thomas was contacted by phone and indicated they had extensive experience in coal handling and feeding.

${ }^{7}$ See Bibliography for references 
However, much of their work is custom designed, custom built, and somewhat proprietary to their clients' restricting the amount of information that could be divulged. He had worked on some plug feed extrusion devices that operated to $1600^{\circ} \mathrm{F}$ at low pressure, 5 to $15 \mathrm{psig}$. They did not operate at a differential pressure but he felt that a plug could be formed that would seal at modest differential pressure, in the range of $30 \mathrm{psi}$. He indicated that while they had no off-the-shelf equipment to perform the function we desired, they would be very willing to do some development work in this area. In fact, his associate, Al Glover, had been approached several times recently on an application similar to ours and as a result they were planning to run a few demonstration tests using standard component.s. How far they would proceed would depend on the results obtained and continued demonstrated market interest. Apparently there was presently no off-the-shelf equipment to perform this feeding function and a development project would be required to provide one. Werner \& Pfleiderer Corporation 8

Werner \& Pfleiderer are located in Stuttgart, Federal Republic of Germany with a United States Office at 663 E. Crescent Ave., Ramcey, New Jersey 07446, telephone (201) 327-6300. They are primarily involved in plastics technology, polymer processing, and twin screw extrusion systems. They have been involved in trying to transfer the plastics technology to the feeding of coal using twinscrew extruders since 1971. John Stewart supplied numerous t.erhnisal documents and brochures. He also indicated a $120 \mathrm{~mm}$ (approximately 4 3/4") twin screw ZSK type extruder had been feeding coal to a pressurized reactor in the Federal Reputilic of Germany for about a year. The company (VEBA Oel Ag) was contacted by letter but no response has been received.

The Werner \& Pfleiderer ZSK type extruder employs co-rotating intermeshing screws where one screw "wipes" the other screw as they revolve and effects a positive displacement pumping action. This technique has demonstrated feeding of a high solids content ( $80 \%$ by weight) coal slurry at $800^{\circ} \mathrm{F}$ and a differential pressure of $3000 \mathrm{psid}$. Feedstocks to $-1 / 2$ inch maximum have been accommodated.

See Bibliography for references 
Screw extruder technology as applied to pumping plastics at several thousand ps $i$ is a mature science but plastics industry technology generally does not work with coal. Bench scale single screw testing with coal slurries demonstrated 1000 psid operation. However, larger scale testing resulted in numerous problems with caking, wear, blowback, etc. Twin-screw Werner \& Pfleiderer type extruders have overcome many of the single-screw problems; 1500 psid operation has been demonstrated. Sized coal is required; $-1 / 4$ inch maximum is indicated. Double screening may be required. Werner \& Pfleiderer claim they are ready to supply twin-screw pumps (commercial units) for long term service on high pressure gasification or liquefaction equipment.

In addition to the above contacts, the book Coal Gasifiers by E. J. Hoffman (1981) was reviewed and the two feed systems mentioned there in were researched. Acrison Inc. of 20-T Empire B1vd., Moonachie, N.J. 07074, telephone (201) 440-8300 and Bloomer-Fiske, Inc. of 4016 S. Princeton St., Chicago, IL 60609, telephone (312) 523-2300 were contacted by phone. Neither was aware of any off-the-shelf equipment to perform to our requirements. Acrison, Inc. provides precision feeding/metering of coal, normally pulverized, using gravimetric methods such as weight belts. They are not involved in any sort of pressurized feeding which they implied was done with "locks". Bloomer-Fiske, Inc. are a contract manufacturer. They have no product per se but make custom equipment to clients' drawings and specifications. They do not have the expertise to engineer a feeder and suggested contacting Screw Conveyor Corporation which was reported on above.

Don Lewis at JPL suggested talking to Welex, Inc., 850 Jolly Rd., B1ue Be11, PA 19422, telephone (215) 542-8000, who had participated in the early work in coal extrusion. Frank Nissel was contacted and indicated that the numerous problems with coal properties, e.g., going from "rocks" to.a highly viscous liquid within the extruder, make the single screw extruder a poor candidate for feeder service. Part of the problem is that the single screw extruder, commonly thought of as a positive feed device is really not. Propulsion of the material through the extruder is related to friction between the material being transported and the screw and barrel surfaces. If adequate friction is not developed the material tends to stay in one place, simply tumbling over on itself as the screw turns. There is no positive displacement feature such as a piston moving in a cylinder since the screw does not normally translate relative to the barrel. Detailed design 
information can be found in Section 3.0 Existing Literature and Design Information of DOE Document EY-77-C-27-8085-004-19. Welex thought that a twin screw extruder or a combination single screw/gear pump arrangement would be appropriate. While both these techniques are commercial in the plastics industry, Welex knew of no commercial applications feeding coal. It was inferred from the discussion with Welex that coal feeding with a screw type device at differential pressure of any magnitude was still in the development or even research stage.

The Institute of Gas Technology (IGT), 3424 State St., Chicago, IL 60616, telephone (312) 567-3650, was mentioned as having done a lot of feeder development work by one of the sources contacted (George Schultz, A. Epstein and Sons, Chicago, IL). IGT was contacted (Dr. Ted Knowlton) and they indicated that they had done some proprietary feeder work in the oil shale area but that the differential pressures involved were minimal, certainly. less than 5 psid. They mentioned the equipment they used came from Screw Conveyor Corporation and Thomas \& Muller Company, both of which were reported on above. It was inferred from the discussion held with IGT that screw conveyor/feeder equipment was not suitable for our intended application, at least not at this time. Trying to form a high pressure (500 to 1000 psid) gas seal using run of mine coal as a feedstock is just not state-of-the-art. Larger coal particles (greater than $1 / 8-1 / 4$ inch), even when compressed by existing screw feeder type devices, afford too large a void (flow path) area to effect a gas seal of any magnitude. Feedstock size reduction and the use of binders would help. However, it was suggested that the Kamyr feeder device might meet the requirements ${ }^{10}$. Since this device was not a screw type, it was not pursued as part of this survey. The information loop appeared to be closing (source references being repeated) and the survey was terminated at this time.

9 "Coal Extruder Test Program, Coal Extrusion Present Technology" by TRW Energy Systems Planning Division, DOE Contract No. EY-77-C-21-8085, Document No. EY-77-C-21-8085-004-1, March 1978.

10 "Continuous Injection of Coal to Pressurized Pipelines and Processes by Rotary Lock Chamber Exchange of Macro-Volumes of Low Pressure Slurry for Equal Volumes High Pressure Liquid", Erwin D. Funk, Kamyr, Inc., Glens Falls, NY. 


\subsection{CONCLUSIONS}

The basic conclusion from the survey is that screw type devices to replace lockhopper systems for feeding coal to pressurized reactors do not exist as off-the-shelf equipment. Two screw type devices were found that have been used to feed coal across a pressure boundary. One has extensive service and is a commercial item - the Type M Fuller-Kinyon pump. The other, purportedly commercial but with much less service experience, is the Werner \& Pfleiderer twin-screw extruder. The former is 1 imited to the 50 to $100 \mathrm{psi}$ differential pressure range and is primarily used to supply atmospheric coal to pressurized pneumatic transfer systems for fluid bed boilers. The latter develops much higher pressure - in the severai thousand psi range - but requires the addition (or inherent) of $20 \%$ moisture. Both require sized coal, nominally less than $1 / 2$ inch. The Type $M$ pump has the advantage of design maturity and a reliable service record. However, extension of the differential capability above a few hundred psi is questionable even with major modifications. The Werner \& Pfleiderer unit has the very distinct advantage of being a positive displacement type device. Cost is inferred to be a disadvantage. In addition, a service record must be developed.

Equipment in use in the biomass field, particularly wood products, conceivably can be modified or converted for coal application. These commercial devices were found to perform satisfactorily with wood products (chips, pulp, sawdust, etc.) in the 150 psid range. The consensus is that development work would be required before coal service could be realized.

Deviccs other than screw type feeders are availahle to feed coal. These include commercial systems such as Petrocarb, Lurgi, and other lockhopper systems including the Kamyr rotary lock feeder, and DOE sponsored feeders being developed by Conspray, Lockheed, Ingersoll-Rand, and Foster-Miller, Inc. 
Few companies are presently involved in developing coal applications for their existing commercial equipment. Fuller company did not indicate that they were trying to extend greatly their differential pressure range to the $100+$ psi level. Werner \& Pfleiderer are actively engaged in coal applications/ developments. Thomas \& Muller proposed performing some "demonstration" tests at their own expense. Many expressed a willingness to co-operate in developments if funding was available. A few were not interested in coal research or development efforts sponsored by government. Several were quite satisfied to act as fabricator to client prints but lacked the expertise to engineer a coal feeder product.

In short, commercial, standard, off-the-shelf screw type feeders do not exist that will take run of mine coal at atmospheric conditions and transport it across a pressure barrier above $150 \mathrm{psid}$ and afford a positive seal. This is still basically the domain of lockhopper and slurry pump type systems. 


\subsection{RECOMMENDATIONS}

Specific recommendations resulting from the survey are difficult to formulate. One is to monitor the progress of the Werner \& Pfleiderer twin-screw extruder feeder. Efforts to increase the size of the feedstock and decrease the amount of added moisture should be encouraged.

The probability of commercial biomass feeders to operate with coal should be assessed by demonstration tests using existing equipment. An arrangement for doing this needs to be fashioned with the manufacturers. Candidate equipment includes the Stake Technology "Co-Axial Feeder", the Koppers Plug Screw Feeder, and the C.E. Bauer Plug Screw Feeder; emphas is should be placed on the Stake unit.

Al though the bulk of the manufacturers/users of screw feeding equipment are doubtful of pressure sealing applications, some interest was expressed. Therefore, the capability to feed coal to a pressurized reactor using a commercial, off-the-shelf, screw conveyor/feeder to CEMA standards should be determined. An integrated/cost sharing effort with selected manufacturers could accomplish this. Results of the tests should be sufficient to ascertain the applicability of that equipment for this application. Thomas and Muller Co., Inc., Fuller Company, and Ferro-Tech are suggested for initial contacts.

The requirements for coal feeders need to be definitized. A specification, or series of specifications, should be developed that address particular criteria, e.g., the characteristics of the feedstock and the output product. Temperature, pressure, and leakage rate ranges should be stated. The specification(s) may need to be process specific, e.g., fixed-bed, fluidized-bed, etc. These specifications would benefit manufacturers by presenting specific values as opposed to generalized statements and could serve as a connecting link to an end item use to which the manufacturers could relate. 


\subsection{BIBLIOGRAPHY}

1. Ferro-Tech, General Catalog (FT 306), selected bulletins (FT 302, 304, 305) and technical papers: "Agglomeration-The State of the Art"; "Briquetting and Compacting"; "Disc Pelletizing Theory and Practice"; "Binders and Binder Systems for Agglomeration"; "Agglomeration of Coal Fines".

2. Miles, Thomas R., Consulting Design Engineer, selected papers: "Preparation of Biomass for Gasification" March 1982; "Some Biomass Conversion Reference Data" December 1982.

3. Levelton, B.H. and Associates Ltd., Contractor's Final Report, "Status of Biomass Feeder Technology", ENFOR Project C-259, DSS Contract 43SS. KN107-1-4420, Canadian Forestry Service, December 1982.

4. FMC, Catalog, "Link-Belt Screw Conveyors and Screw Feeders", Document No. 011 A57815.

5. Conveyor Equipment Manufacturers Association, "Conveyor Terms and Definitions", CEMA No. 102-1982, Fourth Edition, 1982.

6. Conveyor Equipment Manufacturers Association, "Screw Conveyor Dimensional Standards", CEMA Standard No. 300, ANSI/CEMA 300-1981.

7. Conveyor Equipment Manufacturers Association, "Screw Conveyors", CEMA Book No. 350, ANSI/CEMA 350-1981, Second Edition, 1980.

8. Conveyor Equipment Manufacturers Association, "Classification and Definitions of Bulk Materials", ANSI/CEMA 550-1980, First Edition, 1970.

9. Fuller-Kinyon Systems brochure (Bulletin FK-34) and other miscellaneous brochures relative to the Fuller-Kinyon pump (G-39, ER-G-19, ER=49-5, and Ad No. 1801).

10. Hilbert, J.D., Jr., P.E., Fuller Company, Bethlehem, PA, "Application of a Screw-Type Pump for Coal Feeding", paper given at the AIChE CPE IIIAnaheim Meeting, Anaheim, Califurnia, June 7-9, 1982. 
11. Screw Conveyor Corporation, Catalog, "Screw Conveyor Catalog and Engineering Manual", Catalog No. 575A, 1978.

12. Thomas \& Muller Co., Inc., "Screw Conveyors, Screw Feeders, and Screw Conveyor Drives", Camden, New Jersey 08101, 1973.

13. Werner \& Pfleiderer Corporation bulletins and brochures: "Twin-screw Feed Systems for Coal Reactions", WP4B-81-PTG-1; "ZSK Twin-screw extrusion systems" WPI-81-PTG-6; "Plastics technology" VF 05 048/1-2.0V.79 GSP KH + WH; and "Status Report on Werner \& Pfleiderer Twin Screw Coal Feeder", June 1979.

14. Mack, W.A., Dr., et al., Werner \& Pfleiderer Corporation, "New Technology for Feeding Coal Against High Pressure for Gasification/Liquefaction Operation", November 1981.

15. Hoffman, E.J., The Energon Company, "Coal Gasifiers", 1981. 


\subsection{APPENDIX}

Screw Feeder Survey Letters

and

Mailing List 


\section{TRW}

Manufacturer of Screw Feeder Equipment

The Department of Energy (DOE) and the Morgantown Energy Technology Center (METC) have been involved in evaluating and developing solids feeders for application in advanced coal conversion processes. TRW is currently assisting METC to determine and document the current status of coal feeders.

In order to provide the broadest base, it is necessary to survey manufacturers of screw feeders to obtain the latest available data on screw feeders that are capable of feeding solids against a differential pressure. Therefore, the following information on your screlv feeders is desired:

- Differential pressure against which solids can be fed

- Feed rates

- Coal size range and any other limitations on coal properties (moisture content, volatile level, etc.)

- Feeder size 1 imitations

- Temperature limitations

- Specific power consumption

Higher differential pressure applications are of special interest for the advanced processes that are using higher pressures for improved conversion efficiencies.

Catalogs, drawings, specifications, etc. that you have would be most nelpful in our survey and assessment of the current state of the art in screw feeders.

Should you have any questions or require clarification, please contact Gordon Sine or me at (304) 599-8622. Your assistance is sincerely appreciated.

DAM: va

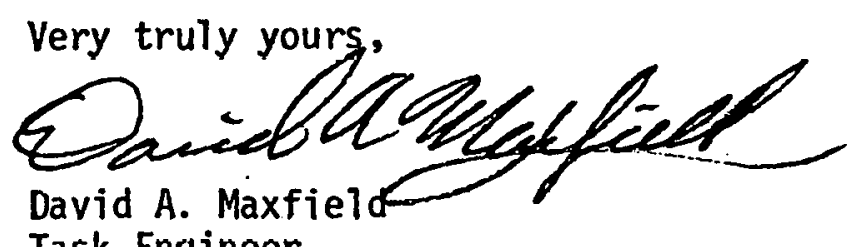

Task Engineer 
Organizations/Trade Associations

The Department of Energy (DOC) and the Morgantown Eneryy Techmulugy Center (METC) have been involved in evaluating and developing solids feeders for application in advanced coal conversion processes. TRW is currently assisting METC to determine and document the current status of coal feeders.

In order to provide the broadest base; TRW is surveying manufacturers of screw feeders to obtain the latest available data. Our particular interest at this time is screw feeders that are capable of supplying solids to a pressurized vesse1. In addition, we are interested in keeping abreast of the state of the art and potential new developments through contact and familiarization with the industry in general. It is in this latter thrust that I am writing your association for further enlightenment.

A number of questions have developed in our search for data. It would be very helpful if you could respond to the following:

- Does your association include within its scope of operations equipment for screw feeders for industrial coal conversion processes?

- Does your assocation hold annual conventions? If so, does it include displays by exhibitors? What is your schedule of meetings?

- Do you know of other associations or sources that would provide opportunities for technology transfer and interaction with industry representatives?

- Does your assocation publish equipment information in papers or proceedings? If so, do you have a library or listings for review?

Should you have any questions or require clarification, pleasc contact Gordnn Sine or me at. (304) 599-8622. Your assistance is sincerely appreciated.

Very truly yours,

DAM: va

David A. Maxfield Task Engineer 


\section{TRW}

Knowledgeable Individual

Our company is conducting a survey of screw feeder manufacturers as part of a task being performed for the Department of Energy. The specific task manager is Dave Dubis of the Morgantown. Energy Technology Center. Because of your past involvement in solids feeding, we hope that you will be able to review the list of manufacturers to whom the initial information request is being sent and suggest additional contacts. A sample letter and the list of addressees for the first mailing is enclosed.

Thank you very much for your assistance in this matter.

Very truly yours,

DAM:va

Enc. as noted
David A. Maxfield

Task Engineer 
Manufacturers

Acrison Inc.

20-T Empire Blvd.

Moonachie, NJ 07074

Bloom Inc.

U.S. Highway $W$

Independence, IA 50644

Buck-El, Inc.

24-T Commerce Street

Chatham, NJ 07928

Divine Engineering, Inc.

P.0. Box 1345

Cedar Rapids, IA 52406

Duplex Mill \& Manufacturing Co.

The 400 Sigler Street

Springfield, $\mathrm{OH} 45501$

Eriez Magnetics

1386 01d Freeport Road

Pittsburgh, PA 15238

Ferro-Tech, Inc.

467 Eureka Road

Wyandotte, MI 18192

FMB Systems, Inc.

151-T Main Street

Lodi, NJ 07611

Foster-Miller Associates, Inc. 350 Second Avenue Wal tham, MA 02754

Adi R. Guzzdar

General Electric Co. P.0. Box 8, River Road Schenectady, NY 12301

A. H. Furman

Dr. Ralph R. Boericke
Bechtel Natfonal

P.0. Box 3965

San Francisco, CA 94119

M. K. V. Chari

A. E. Bogott \& Sons, Inc.

110 Third Avenue

Sterling, IL 41081

Conspray Construction Systems, Inc.

111 W. Dyer Road, Suite B

Santa Ana, CA 92707

Douglas D. Peterson

Ducon Company, Inc.

Ducon Fluid Transport Division

842 First Avenue

King of Prussia, PA 19406

James Eagen \& Sons Co.

204 W. 8th Street

Wyoming, PA 18644

Feedmatic-Detroit, Inc.

4660 E. 355th Street

Cleveland, $\mathrm{OH} 44094$

Flex-Kleen Corp.

Attn: Marketing Department

One NorthWestern Center

$165 \mathrm{~N}$ Canal street

Chicago, IL 60606

FMC Corp.

Material Handling Equipment Div.

llomer City, PA 15748

Fuller Company

Box 2040

Bethlehem, PA 18001

Henderson Industries

45-T Fairfield Place

West Caldwe11, NJ 07006 
Horst Dynamics, Inc.

Denver, CO 80236

Ingerso 11 -Rand

Box 301

Princeton, NJ 08540

Dil ip Mistry

Kinergy Corporation

4821 Jennings Lane

Louisville, KY 40218

Lively Manufacturing

and Equipment Co.

P.0. Box 339

Glen White, WV 25849

MMM Mars Mineral

P.0. Box 128

Valencia, PA 16059

Mikropul Corporation

Pulverizing Machinery Division

26 Chatham Road

Summit, NJ 07901

Nash International Inc.

6548 Carmel Road

P.0. Drawer 221301

Charlotte, NC 28222

Nott Company

Engineered Material Handling Division

1722 New Brighton Blvd.

Minneapolis, MN 55413

Petrocarb, Inc.

200 Broadacres Drive

Bloomfield, NJ 07003

Harold Reintjes

Thomas \& Muller Co., Inc.

Box 1930

Camden, New Jersey 08101
IFE Systems, Inc.

370-B Franki in Turnpike

Mahawah, NJ 07430

Jeffrey Manufacturing

Division Dresser Industries, Inc.

41 Fisher Avenue

Bradford, PA 16701

K-Tron Corporation

20 Warrick Avenue

Glassboro, NJ 08028

Lockheed Dept. 52-33

P.0. Box 504 Building $131 \mathrm{~T}$

Sunnyvale, CA 94086

John H. Bonin

Dr. John W. Meyer

Metalfab, Inc.

140 Woodland Avenue

Rochelle Park, NJ 07662

Moksnes Mfg., Inc.

Accu-Rate Division

746 E. Milwaukee Street

Whitewater, WI 53190

New Castle Industries, Inc.

Feed Screws Division

925 Industrial Street

New Castle, PA 16102

Penn Bangor, Inc.

R.D. 2. (Jacktown Industrial Park)

Bangor, PA 18013

Sprout-Wa]dron

Koppers Co., Inc.

Muncy, PA 17756

Union Carbide/Nuclear Division

Oak Ridge National Laboratory

Building 1000

P.0. Box $X$

Oak Ridge, TN 37830

B. T. Thompson 
Vibranetics, Inc.

P.0. Box 21219

Louisville, KY 40221

Werner \& Pfleiderer

663 E. Crescent Avenue

Ramsey NJ 07446

John Casey

Wyssmont Company, Inc.

1479 Bergen BTvd.

Fort Lee, NJ 07024

Organizations

Association of Professional

Meterial Handling Consultants (APMHC)

1548 Tower Road

Winnetka, IL 60093

Deep Foundations Institute

P.0. Box 1043

Clifton, NJ 07014

Material Handling Equipment

Distributors Association

201 Route 46

Vernon Hil1s, IL 60061

Petroleum Equipment

Suppliers Association

1703 First City National Bank B1dg.

Houston, TX 77002

Individuals

nnn W. I ewis

Mail Stop 522-310

Jet Propulsion Laboratory

4800 Oak Grove Drive

Pasadena, CA 91103
Vibra Screw, Inc.

755 Union B1vd.

Totowa, NJ 07511

Willis \& Paul Engineers, Inc.

400 Morris Avenue

Denville, NJ 07834
Conveyor Equipment Manufacturers

Association (CEMA)

1000 Vermont Ave., N.W., Suite 1200

Washington, D. C. 20005

International Material

Management Society

3310 Bardaville Drive

Lansing, MI 48906

Material Handling Institute

1326 Freeport Road

Pittsburgh, PA 15238 lames 1. Powell

U.S. Department of Energy

FE 44 - Room E3UY

Germantown

Washington, D. C. 20545 


$$
\text { DOE }
$$

\author{
$\mathrm{OE}$
}

